\title{
Cognitive Algebra Underlying High School Student's Self-Efficacy Judgment to Solve Mathematical Problems in the Classroom or Online
}

\author{
Carlos Briones-Rodriguez ${ }^{1}$, Guadalupe Elizabeth Morales-Martinez ${ }^{2, *}$, Maria Guadalupe \\ Santos-Alcantara ${ }^{3}$, Ernesto Octavio Lopez-Ramirez ${ }^{4} \&$ Maria Elena Urdiales-Ibarra ${ }^{4}$ \\ ${ }^{1}$ Master in teaching for middle higher education (MADEMS) Mathematics, National \\ Autonomous University of Mexico (UNAM). \\ ${ }^{2}$ Cognitive Science Laboratory, Institute of Research on the University and Education, \\ National Autonomous University of Mexico (UNAM; IISUE) \\ ${ }^{3}$ Department of Psychology, National Autonomous University of Mexico (UNAM) \\ ${ }^{4}$ Cognitive Science Laboratory, Department of Psychology, Nuevo Leon Autonomous \\ University (UANL) \\ *Corresponding author: Instituto de Investigaciones sobre la Universidad y la Educación \\ (IISUE), UNAM. Circuito Cultural Universitario, Coyoacán 04510, D.F., México. Tel: \\ 55-5622- 6986/95 Ext. 2120 E-mail: gemoramar@hotmail.com
}

Received: March 5, 2016 Accepted: June 20, 2016 Published: June 24, 2016

doi:10.5296/ije.v8i2.9148 URL: http://dx.doi.org/10.5296/ije.v8i2.9148

\begin{abstract}
This study includes a sample of 112 high school students who provided self-efficacy judgments to solve math problems. Thirty-six experimental conditions called scenarios were created for this study by combining 4 factors regarding solving mathematical problems (modality, degree of difficulty, structuring, and relevance of the task). Each scenario described a hypothetical context that required the participant to imagine an activity to reinforce the learning of math skills in the scenario. Thus, the experimental task was to read each scenario and to judge how capable the participant felt to undertake each math task under the hypothetical context. Results showed two levels of self-efficacy judgment among participants. Students in the first level judged themselves as highly capable of performing math activities, while those in the second level, judged themselves as moderate capable. Regarding the first cluster factors regarding difficulty and the structure of the task had a greater weight whereas in the second cluster task difficulty and task relevance factors obtained the higher weight values. Finally, a cognitive summation rule used by participants to integrate information from the different study factors was identified. Results implications on education are discussed in this article.
\end{abstract}

Keywords: Self-efficacy, cognitive algebra, mathematics online, classroom, high school students. 


\section{Introduction}

Students face challenges in their learning process on a daily basis, some of these happen almost naturally and others are created and directed. For example, teachers create experiences inside and outside the classroom (exams, homework, exercises in class, etc.) with the goal of helping students reach the learning of a specific domain (algebra, geometry, etc.). The objectives of the experiences will not always be met. Factors related to the context, the learning task, and especially the student play an important role so that those experiences can have a real effect in the learning process. Of special interest are the variables related to the beliefs that the student has about her/his ability to perform inside class activities. This is because people contribute to their own learning performance through mechanisms of personal agency. For instance, a central agency mechanism relates to "perceived self-efficacy” (Bandura, 1995). "Perceived self-efficacy is concerned with judgments of how well one can execute courses of action required to deal with prospective situations” (Bandura, 1982, p.122). Of particular interest to the current study is academic self-efficacy, which refers to the beliefs that the student has regarding their learning capacity.

Ziummerman, Bandura, and Martinez-Pons (1992) argue that perceived self-efficacy within the academic context appears to be a significant predictor of learning performance (see Bong \& Skaalvik, 2003; Skaalvik \& Skaalvik, 2008). It also serves as an achievement mediator (Moriarty, Douglas, Punch \& Hattie, 1995) and a modulating factor regarding the amount of effort a student expends and the persistence they exhibit (Zeldin \& Pajares, 2000); it is also a factor with regards to the motivational, affective, and cognitive processes of students during learning (Bandura, 1995).

A number of researchers have explored the psychological nature of the beliefs of efficacy in order to determine the effect that these beliefs have on learning performance in different knowledge domains (e.g., chemistry: Dalgety \& Coll, 2006; computer science: Lin, 2016; music: Hendricks, 2015, Hendricks, 2014; mathematics: Özyürek, 2005; Lent, Brown, Gover, \& Nijjer, 1996). For instance, the beliefs of effectiveness in mathematics have been widely explored from quantitative and qualitative perspectives (see Usher \& Pajares, 2008; Usher, 2009), using instruments such as questionnaires and Likert scales (e.g., Cheema \& Kitsantas, 2014; Peters, 2013; Bagaka's, 2011), experimental designs (e.g., Hung, Huang \& Hwang, 2014), and interviews (e.g., Tirosh, Tsamir, Levenson, Tabach, \& Barkai, 2013). The aforementioned research has been applied to different samples (kindergarten students: Tirosh et al., 2013; primary school: Hung et al., 2014; Schweinle \& Mims, 2009; high school: Ozgen, 2013; Lopez \& Lent, 1992; Lent, Lopez, Brown, \& Gore, 1996; university education: Turgut, 2013; Lent, Lopez, \& Bieschke, 1991; Matsui, Matsui \& Ohnishi, 1990, etc.). The reproach has also been undertaken in several countries (e.g., Turkey: Turgut, 2013; Ozgen, 2013; Kenya: Bagaka's, 2011; Australia: McConney \& Perry, 2010; Japan: Matsui et al., 1990; Portugal, Poland, Canada, New Zealand, Mexico, Colombia, etc.: OECD, 2013).

These investigations have explored the perceived self-efficacy of students in the context of mathematics based on demographic variables (e.g., gender: Louis \& Mistele, 2012; Huang, 2013; Turgut, 2013; socioeconomic status: Wiederkehr, Darnon, Chazal, Guimond, \& 
Martinot, 2015; McConney \& Perry, 2010; ethnicity: Schweinle \& Mims, 2009; context: Peters, 2013; Cheema \& Kitsantas, 2014; features of the teacher: Bagaka's, 2011; grade level: Turgut, 2013; student learning styles: Ozgen, 2013; academic performance: Turgut, 2013; task mode: Hung et al., 2014).

In general, evidence collected to supports the idea that self-efficacy beliefs have a direct effect on performance in mathematics. For example, the OECD (2013) conducted a study (PISA 2012) in more than 60 countries concerning students' self-related beliefs of self-concept and self-efficacy, as well as their commitment and participation in mathematic activities inside and outside the school environment. The results indicated that self-efficacy was strongly associated with math performance at the country level; the results also demonstrated that students who showed low levels of self-efficacy performed at a lower level than those who relied on their skills to undertake math tasks. This seems to relate to the fact that students who rely more on their abilities tend to monitor their working time more effectively, exhibit greater persistency, and use self-regulation strategies that promote their success in school (Schunk \& Pajares, 2002).

Academic self-efficacy studies indicate that there are at least four relevant sources of information dealing with students' self-efficacy beliefs on mathematics and other knowledge domains. These include: prior experience (which seems to be the most influential factor) vicarious experiences, social persuasion, and physiological states. The magnitude of the influence of these sources on students' perceived self-efficacy differs depending on factors such as gender, ethnicity, academic ability, and the academic domain (Usher \& Pajares, 2008). However, the influence of these sources becomes more apparent in specific domains. For example, in the field of writing, girls reported to be more influenced by previous experiences and experienced reduced levels of anxiety than boys (Pajares, Johnson, \& Usher, 2007), whereas in the domain of science (Britner \& Pajares, 2006) and mathematics, the development of self-efficacy in male students seems to be more influenced by previous experiences in their sense of self-efficacy (Lent et al., 1996) and the confidence of women seems mainly influenced by social persuasion factor (Lopez, Lent, Brown, \& Gore, 1997; Lopez \& Lent, 1992). For instance, women's perceived self-efficacy is more oriented to their relationship with others rather than oriented to themselves (Usher \& Pajares, 2008). However, it is important to mention that other research findings are not consistent with gender differences observed in these studies (e.g., Matsui et al., 1990; Lent et al., 1991).

Students' judgments of self-efficacy are not only influenced by their gender or the academic domain in which they are generated; rather, other individual and contextual factors may also shape their judgments. For example, social models to which they are exposed might also influence students. Most of these models are in the family environment, the school, or the ethnic group to which they belong. Some studies suggest that the influence of previous experience is higher in white students (Smith, 2001), while vicarious experiences seem to have greater weight among Hispanic students (Stevens, Olivarez, \& Hamman, 2006).

Student characteristics are also influence factors for self-efficacy. Ozgen (2013) found that self-efficacy beliefs in mathematics differ in terms of students' learning style. Ozgen 
observed that students with a convergent learning style possess higher self-efficacy beliefs, while those students with a divergent leaning style mostly have low or moderate self-efficacy levels. In addition, students' ability to self-regulate their learning seems to be a way to balance their confidence, reduce their anxiety, and master learned material (Usher, 2009).

In sum, existing research has provided relevant information, helping us to understand the origin, structure, and operation of academic self-efficacy, in particular in the domain of mathematics. In order to understand the psychological nature of perceived self-efficacy, it is necessary to explore the cognitive mechanisms of integration of information that underlie the efficacy beliefs in different circumstances and through different sources (Usher \& Pajares, 2008). One way to approach this problem is through the cognitive algebra paradigm provided by the information integration theory (IIT, Anderson, 1982). The central point of this theory is to find the cognitive-psychological laws of information processing underlying superior thinking.

As such, the cognitive IIT approach has proved to be a very useful tool for determining patterns of cognitive behavior regarding the way people systematically integrate sources of information in different psychological fields (e.g., attitudes toward school and work: Morales, Lopez, Villarreal, Montalvo, Mezquita,, \& Castro, 2014; Morales-Martínez, Lopez-Ramirez, Villarreal-Treviño, \& Mezquita-Hoyos, 2015; love: Falconi \& Mullet, 2003; sexuality: Esterle, Munoz-Sastre \& Mullet, 2008; Morales, Lopez, Esterle, Munoz-Sastre \& Mullet, 2010; medical concerns: Hervé, Mullet \& Sorum, 2004; interpersonal relationships: Farkas, 1991; Bioethics: Mullet, Sorum, Teysseire, Nann, Morales, Ahmed, Kamble, Olivari, \& Munoz-Sastre, 2012) through different levels of processing.

\section{The Present Study}

In accordance with the IIT approach, the present study applies a cognitive algebra design to find cognitive algebraic rules through which high school students integrate different pieces of information (the difficulty, structure, form, and relevance of the math assignments) when they evaluate their own ability to solve math problems either online or inside the classroom. The method adopted by this study as follows.

\section{Method}

This research aimed to explore the cognitive mechanisms underlying high school students' judgments of self-efficacy in the context of learning mathematics. To achieve this, the following information integration study (Anderson, 1982) was implemented.

\subsection{Design}

The experimental design consisted of an orthogonal combination of four factors: Learning mode (virtual vs. face-to-face), degree of task's difficulty (high vs. low), degree of instruction structure (low vs. middle vs. high) and relevance of the learning task (high vs. medium, vs. 
low). This combination resulted in 36 experimental conditions, which were used to build the instrument.

\subsection{Instrument}

The instrument consisted of 36 experimental conditions obtained from the combination of the aforementioned 4 factors and their sub-factor levels. Each condition represented an experimental scenario, which briefly described a mathematics activity. At the end of each scenario, a question was presented about the perceived level of self-efficacy to carry out the mathematical task; the question was accompanied by a scale from 0 to 10 points (see Appendix 1 for an example of a scenario).

\subsection{Participants}

This study involved 112 Mexican high school students. The sample age range was between 14 and 18 years $(M=15.5, D E=.9), 47 \%$ of which were female and 53\% were male. None of the students were married. Moreover, all students participated voluntarily and did not receive any financial compensation.

\subsection{Procedure}

The application of the study comprised of three phases. In the first phase, verbal consent was obtained from all participants to voluntary take part in the study; all participants were assured of confidentiality. Subsequently, each participant received instructions and a practice series of scenarios so they could familiarize themselves with the experimental task. Finally, participants were required to read the 36 scenarios and judge their ability to carry out each task. The time required to complete the study varied between 40 and 50 minutes.

\section{Results}

A cluster analysis was conducted on the raw data of all participants (K-means, Euclidian distances) to determine if the trials to test for efficacy could be grouped into different points of view. Subsequently, for each identified group, an ANOVA was carried out. The objective to this analysis was to explore the algebraic cognitive nature underlying the sample groups' response patterns by using interaction ANOVA graphs.

\subsection{Cluster analysis}

The analysis revealed significantly different response patterns $\left(\eta^{2}=0.63\right)$ among the participants. The first cluster ( $\mathrm{N}=81,73 \%$ ) was formed by a group of people who are considered highly capable of solving mathematical tasks $(M=8)$, regardless of the mode (virtual, $\mathrm{M}=8$; face-to-face in site, $\mathrm{M}=8$ ). This cluster was named the high self-efficacy group. The second cluster $(\mathrm{N}=31,27 \%)$ was comprised of people who perceived themselves as moderately capable of solving mathematical tasks in various situations $(M=5)$, regardless of the form of the task (virtual, $M=5$; or face-to-face in site, $M=5$ ). For this reason, this cluster was called the moderate self-efficacy group. 
4.2 ANOVA

For each cluster, a 2x2x3x3 ANOVA was carried out which considered factors of learning mode, degree of difficulty, degree of instruction structure, and relevance of the learning task. Analysis significance was set at $\mathrm{p}<0.001$.

Table 1. ANOVA results for each cluster

\begin{tabular}{|c|c|c|c|c|c|c|c|}
\hline Source & $d f$ & $M S$ & $d f$ & MS & $\mathbf{F}$ & $p$ & $\eta^{2}$ \\
\hline \multicolumn{8}{|c|}{ Cluster $1<<$ High self-efficacy $>>$} \\
\hline Mode (M) & 1 & 12.4 & 80 & 1.5 & 8.444 & ns & 0.09 \\
\hline Difficulty (D) & 1 & 967.9 & 80 & 8.8 & 109.852 & 0.001 & 0.57 \\
\hline Structure (E) & 2 & 24.6 & 160 & 2.5 & 9.739 & 0.001 & 0.10 \\
\hline Relevance (R) & 2 & 8.1 & 160 & 3.2 & 2.563 & ns & 0.03 \\
\hline$M * D$ & 1 & 3.9 & 80 & 1.7 & 2.210 & ns & 0.02 \\
\hline $\mathrm{M} * \mathrm{E}$ & 2 & 1.0 & 160 & 1.1 & 0.912 & ns & 0.01 \\
\hline $\mathrm{D}^{*} \mathrm{E}$ & 2 & 1.4 & 160 & 1.3 & 1.078 & ns & 0.01 \\
\hline $\mathrm{M} * \mathrm{R}$ & 2 & 5.9 & 160 & 1.7 & 3.522 & ns & 0.04 \\
\hline $\mathrm{D} * \mathrm{R}$ & 2 & 0.5 & 160 & 1.7 & 0.325 & ns & 0.004 \\
\hline $\mathrm{E}^{*} \mathrm{R}$ & 4 & 0.8 & 320 & 1.1 & 0.712 & ns & 0.008 \\
\hline \multicolumn{8}{|c|}{ Cluster $2<<$ Moderate self-efficacy $>>$} \\
\hline Mode (M) & 1 & 1.43 & 30 & 5.19 & 0.276 & ns & 0.00 \\
\hline Difficulty (D) & 1 & 1837.4 & 30 & 27.25 & 67.428 & 0.001 & 0.69 \\
\hline Structure (E) & 2 & 2.43 & 60 & 2.78 & 0.872 & ns & 0.02 \\
\hline Relevance (R) & 2 & 87.60 & 60 & 7.20 & 12.159 & 0.001 & 0.28 \\
\hline$M * D$ & 1 & 2.06 & 30 & 1.42 & 1.453 & ns & 0.04 \\
\hline $\mathrm{M}^{*} \mathrm{E}$ & 2 & 3.69 & 60 & 2.51 & 1.472 & ns & 0.04 \\
\hline $\mathrm{D} * \mathrm{E}$ & 2 & 0.03 & 60 & 1.88 & 0.017 & ns & 0.00 \\
\hline $\mathrm{M} * \mathrm{R}$ & 2 & 4.88 & 60 & 2.25 & 2.1709 & ns & 0.06 \\
\hline $\mathrm{D} * \mathrm{R}$ & 2 & 8.90 & 60 & 2.10 & 4.2307 & ns & 0.12 \\
\hline $\mathrm{E} * \mathrm{R}$ & 4 & 6.33 & 120 & 2.51 & 2.5189 & ns & 0.07 \\
\hline
\end{tabular}

From these data you can see at least three relevant aspects. First, for both clusters, the most important factor was the difficulty of the task. The second most important factor varies from one group to another; for the cluster of moderate self-efficacy, the importance of the task was the second most important factor, whereas for the high self-efficacy participants, the degree of task structuration was the second most important factor. Finally, it is interesting to note that although the modality of the task (virtual or face-to-face) was not significant $(p>$. 001) for both clusters, the high self-efficacy group obtained a relatively high $F$ value $[F(1,80)=$ $8.4 \mathrm{p}=.004, \eta^{2}=.09$ )] for this factor, suggesting that perhaps this element could acquire greater importance for self-efficacy under certain circumstances when students are solving mathematical problems. 


\section{Macrothink}

International Journal of Education

ISSN 1948-5476

2016, Vol. 8, No. 2

There were no significant interactions in any of the identified clusters. This suggests that each identified cluster (moderate and highly effective) use a summative cognitive rule to integrate information relevant to self-efficacy judgment to solve mathematical problems through trial situations (see Figure 1).
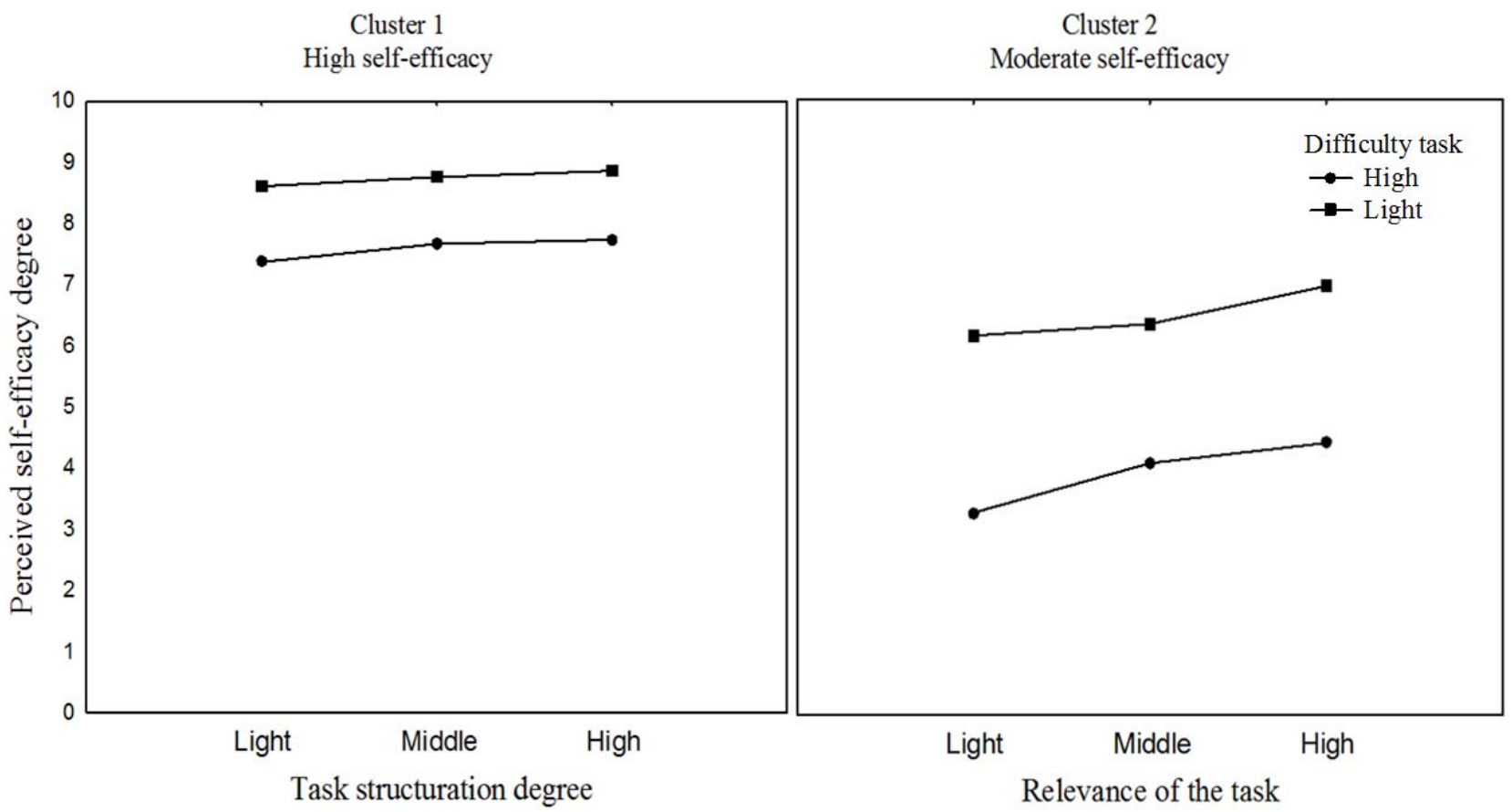

Figure 1. Interaction graph showing how most relevant factors were cognitively integrated by each group

The left panel shows the high self-efficacy group response pattern considering factors of difficulty and degree of task structuration whereas the right panel shows the moderate self-efficacy performance considering factors of difficulty and importance of the task.

\section{Discussion}

This research sought to present experimental evidence about the nature of integration of information cognitive mechanisms underlying the formation of high school students' judgments of self-efficacy in the context of learning mathematics. As indicated by the results, the perception of self-efficacy in the study sample ranged from moderate to high depending first on the difficulty of the task and the structure of the task (high self-efficacy cluster) and secondly on the difficulty of the task and the relevance of the task (moderate self-efficacy cluster) (see Figure 1).

For both groups, the cognitive mechanism of integration of information is governed by an additive rule. This means that the factors considered as the most relevant in the high self-efficacy cluster (difficulty + structure) and the moderate self-efficacy (difficulty + 
relevance) seem to contribute in an orthogonal way to the formation of self- efficacy judgment, although valuation of factors seem to be different for each cluster (Figure 1). Note that the impact of the difficulty of the task is greater when it interacts with the relevance of the task, as shown in cluster 2 (moderate self-efficacy).

A possible hypothesis for group differences may be related to student learning style. Factor selection in both groups hints at students' learning preferences. Goal oriented students achieve learning by weighing different success strategies (high self-efficacy) while the other students focus more on the goal than on weighting a successful learning strategy (moderate self-efficacy). Both approaches have advantages and disadvantages. For instance in virtual learning environments, highly structured specifications assist students to navigate in contexts where teacher synchronous assistance does not exist. A student who requires more structure would benefit from detailed instructions, while her/his learning performance would deteriorate in either environment (face-to-face and virtual instruction) in the absence of such instructions.

It is interesting to note that the group (cluster1) that depends on structuration factors to form their judgments of self-efficacy obtained a relatively high $F$ value $[F(1,80)=8.4 p=.004$, $(2$ $=$. 09)], but not a significant mode factor $(p<.001)$. Thus, depending on the mode of instruction, the task structure can affect student performance; therefore, this element could acquire greater importance under certain circumstances with regards to developing student's perception capacity in the solution of mathematical problems. Students who focus on the relevance of the task have the ability to find ways of solving activities on their own when detailed instructions are absent, however, in both virtual or face-to-face learning environments, they are at risk of ignoring the possibility of obtaining assistance or support from a teacher.

In general, this study showed that the paradigm of cognitive algebra is very useful with regards to exploring the mechanisms of information integration involved in the formation of self-efficacy judgment. Further, it is a very flexible methodological tool that can be used to explore the cognitive contribution of different sources (mastery experience, vicarious experience, social persuasions, emotional and physiological states) in the development and transformation of the perception of self-efficacy through different situations. Moreover, it may be equally applicable to other topics such as academic self-concept, academic identity, etc.

\section{Acknowledgement}

We would like to thank the College of Sciences and Humanities (CCH, Azcapotzalco, UNAM) for proving the facilities required to complete this study. 


\section{References}

Anderson, N. H. (1982). Methods of information integration theory. New York: Academic Press.

Bagaka's, J. G. (2011). The role of teacher characteristics and practices on upper secondary school students' mathematics self-efficacy in Nyanza province of Kenya: a multilevel analysis. International Journal of Science and Mathematics Education, 9(4), 817-842. http://dx.doi.org/10.1007/s10763-010-9226-3

Bandura, A. (1982). Self-efficacy mechanism in human agency. American Psychologist, 37(2), 122-147. http://dx.doi.org/10.1037/0003-066X.37.2.122

Bandura, A. (1995). Exercise of personal and collective efficacy in changing societies. In A. Bandura, Self-efficacy in changing societies. (pp. 1-45). UK: Cambridge University Press. http://dx.doi.org/10.1017/CBO9780511527692

Bong, M., \& Skaalvik, E. M. (2003). Academic self-concept and self-efficacy: How different are they really? Educational Psychology Review, 15(1), 1-40. http://dx.doi.org/10.1023/A:1021302408382

Britner, S. L., \& Pajares, F. (2006). Sources of science self-efficacy beliefs of middle school students. Journal for Research in Science Teaching, 43(5), 485-499. http://dx.doi.org/10.1002/tea.20131

Cheema, J. R., \& Kitsantas, A. (2014). Influences of disciplinary classroom climate on high school student self-efficacy and mathematics achievement: a look at gender and racialethnic differences. International Journal of Science and Mathematics Education, 12(5), 1261-1279. http://dx.doi.org/10.1007/s10763-013-9454-4

Dalgety, J., \& Coll, R. K. (2006). Exploring first-year science students' chemistry self-efficacy. International Journal of Science and Mathematics Education, 4(1), 97116. http://dx.doi.org/10.1007/s10763-005-1080-3

Esterle, M., Muñoz-Sastre, M. T., \& Mullet, E. (2008). Judging the acceptability of sexual intercourse among persons with learning disabilities: French lay people's viewpoint. Sexuality \& Disability, 26(4), 219-227. http://dx.doi.org/10.1007/s11195-008-9093-9.

Falconi, A., \& Mullet, E. (2003). Cognitive algebra of love through the adult life. The International Journal of Aging \& Human Development, 57(3), 275-290. http://dx.doi.org/10.2190/NPQH-MDLX-F48U-AA35

Farkas, A. J. (1991). Cognitive algebra of interpersonal relationship. In N. H. Anderson, Contributions to information integration theory (Vol. 2, pp. 43-99). Hillsdale, NJ.: Erlbaum.

Hendricks, K. S. (2014). Changes in self-efficacy beliefs over time: Contextual influences of gender, rank-based placement, and social support in a competitive orchestra $\begin{array}{llll}\text { environment. Psychology } & \text { of }\end{array}$ http://dx.doi.org/10.1177/0305735612471238

Hendricks, K. S. (2015). The sources of self-efficacy: Educational research and implications for music. Update: Appliations of Research in Music Education, 1-7. 
http://dx.doi.org/10.1177/8755123315576535

Hervé, C., Mullet, E., \& Sorum, P. C. (2004). Age and medication acceptance. Experimental Againg Research, 30(3), 253-273. http://dx.doi.org/10.1080/03610730490447886

Huang, C. (2013). Gender differences in academic self-efficacy: A meta-analysis. European Journal of Psychology of Education, 28(1), 1-35. http://dx.doi.org/10.1007/s10212-011-0097-y

Hung, C. M. (2014). Effects of digital game-based learning on students' self-efficacy, motivation, anxiety, and achievements in learning mathematics. Journal of Computers in Education, 1(2-3), 151-166. http://dx.doi.org/10.1007/s40692-014-0008-8

Lent, R. W., Brown, S. D., Gover, M. R., \& Nijjer, S. K. (1996). Cognitive assessment of the sources of mathematics self-efficacy: A thought-listing analysis. Journal of Career Assessment, 4(1), 33-46. http://dx.doi.org/10.1177/106907279600400102

Lent, R. W., Lopez, F. G., \& Bieschke, K. J. (1991). Mathematics self-efficacy: Sources and relation to science-based career choice. Journal of Counseling Psychology, 38(4), 424430.

Lent, R. W., Lopez, F. G., Brown, S. T., \& Gore Jr., P. A. (1996). Latent structure of the sources of mathematics self-efficacy. Journal of Vocational Behavior, 49(3), 292-308. http://dx.doi.org/10.1006/jvbe.1996.0045

Lin, G.-Y. (2016). Self-efficacy beliefs and their sources in undergraduate computing disciplines: An examination of gender and persistence. Education \& Educational Research, 53 (4), 540-561. http://dx.doi.org/10.1177/0735633115608440

Lopez, F. G., \& Lent, R. W. (1992). Sources of mathematics self-efficacy in high school students. Career Development Quarterly, 41(1), 3-12. http://dx.doi.org/10.1002/j.2161-0045.1992.tb00350.x

Lopez, F. G., Lent, R. W., Brown, S. D., \& Gore, P. (1997). Role of social-cognitive expectations in high school students' mathematics-related interest and performance. Journal of Counseling Psychology, 44(1), 44-52. d http://dx.doi.org/10.1037/0022-0167.44.1.44

Louis, R. A., \& Mistele, J. M. (2012). The differences in scores and self-efficacy by student gender in mathematics and science. International Journal of Science and Mathematics Education, 10(5), 1163-1190. http://dx.doi.org/10.1007/s10763-011-9325-9

Matsui, T., Matsui, K., \& Ohnishi, R. (1990). Mechanisms underlying math self-efficacy learning of college students. Journal of Vocational Behavior, 37(2), 223-238. http://dx.doi.org/10.1016/0001-8791(90)90042-Z

McConney, A., \& Perry, L. B. (2010). Socioeconomic status, self-efficacy, and mathematics achievement in Australia: A secondary analysis. Educational Research for Policy and Practice, 9(2), 77-91. http://dx.doi.org/10.1007/s10671-010-9083-4 
Morales, G. E., Lopez, E. O., Villarreal, M. G., Montalvo, E. S., Mezquita, Y. N., \& Castro, M. E. (2014). Cognitive algebra underlying special education teachers' and psychology students' attitudes towards school inclusion of people with intellectual disability. Journal of Intellectual Disability - Diagnosis and Treatment, 2(1), 33-41. http://dx.doi.org/10.6000/2292-2598.2014.02.01.4

Morales-M, G. E., Lopez-R, E. O., Esterle, M., Muñoz Sastre, M. T., \& Mullet, E. (2010). Judging the acceptability of sexual intercourse among people with learning disabilities: A Mexico-France comparison. Sexuality and Disability, 28(2), 81-91. http://dx.doi.org/10.1007/s11195-010-9147-7

Morales-Martinez, G. E., Lopez-Ramirez, E. O., Villarreal-Treviño, M. G., \& Mezquita-Hoyos, Y. N. (2015). Functional measurement of special education teachers' and students' expectations toward job training for persons with intellectual disability. Journal of Intellectual Disability- Diagnosis and Treatment, 3(1), 35-42. http://dx.doi.org/10.6000/2292-2598.2015.03.01.5

Moriarty, B., Douglas, G., Punch, K., \& Hattie, J. (1995). The importance of self-efficacy as a mediating variable between learning environments and achievement. British Journal of Educational Psychology, 65(1), 73-84. http://dx.doi.org/10.1111/j.2044-8279.1995.tb01132.x

Mullet, E., Sorum, P. C., Teysseire, N., Nann, S., Morales-Martinez, G. E., Ahmed, R., \& Munoz-Sastre, M. (2012). Functional measurement in the field of empirical bioethics. Psicologica, 33, 665-681. Retrieved from http://www.redalyc.org/articulo.oa?id=16924297016

OECD. (2013). PISA 2012 Results: Ready to Learn - Students' Engagement, Drive and Self-Beliefs (Vol. 3 ). PISA, OECD Publishing. http://dx.doi.org/10.1787/9789264201170-en

Ozgen, K. (2013). An analysis of high school students' mathematical literacy self-efficacy beliefs in relation to their learning styles. The Asia-Pacific Education Researcher, 22(1), 91-100. http://dx.doi.org/10.1007/s40299-012-0030-4

Özyürek, R. (2005). Informative sources of math-related self-efficacy expectations and their relationship with math-related self-efficacy, interest, and preference. International Journal of Psychology, 40(3), 145-156. http://dx.doi.org/10.1080/00207590444000249

Pajares, F., Johnson, M. J., \& Usher, E. L. (2007). Sources of writing self-efficacy beliefs of elementary, middle, and high school students. Research in the Teaching of English, 42(1), 104-120.

Peters, M. L. (2013). Examining the relationships among classroom climate, self-efficacy, and achievement in undergraduate mathematics: A multi-level analysis. International Journal of Science and Mathematics Education, 11(2), 459-480. http://dx.doi.org/10.1007/s10763-012-9347-y 
Schunk, D. H., \& Pajares, F. (2002). The development of academic self-efficacy. In A. Wigfield, \& J. Eccles, Development of achievement motivation (pp. 15-31). San Diego, CA: Academic Press. doi: http://dx.doi.org/10.1016/B978-012750053-9/50003-6

Schweinle, A., \& Mims, G. A. (2009). Mathematics self-efficacy: stereotype threat versus resilience. Social Psychology of Education, 12, 501-514. http://dx.doi.org/10.1007/s11218-009-9094-2.

Skaalvik, E., \& Skaalvik, S. (2008). Self-concept and self-efficacy in mathematics: Relation with mathematics motivation and achievement. In F. M. Olsson, New developments in the psychology of motivation (pp. 105-128). Hauppauge: NY: Nova Science Pub.

Smith, S. M. (2001). The four sources of influence on computer self-efficacy. Delta Pi Epsilon Journal, 43(1), 27-39.

Stevens, T., Olivárez, A., \& Hamman, D. (2006). The role of cognition, motivation, and emotion in explaining the mathematics achievement gap between Hispanic and White students. Hispanic Journal of Behavior Sciences, 28(2), 161-186. http://dx.doi.org/10.1177/0739986305286103

Tirosh, D., Tsamir, P., Levenson, E., \& Tabach, M. (2013). Exploring young children's self-efficacy beliefs related to mathematical and nonmathematical tasks performed in kindergarten: abused and neglected children and their peers. Educational Studies in Mathematics, 83(2), 309-322. http://dx.doi.org/10.1007/s10649-012-9458-y

Turgut, M. (2013). Academic self-efficacy beliefs of undergraduate Mathematics education students. Acta Didactica Napocensia, 6(1), 33-39.

Usher, E. L. (2009). Sources of middle school students' self-efficacy in mathematics: A qualitative investigation. American Educational Research Journal, 46(1), 275 -314. http://dx.doi.org/10.3102/0002831208324517.

Usher, E. L., \& Pajares, F. (2008). Sources of self-efficacy in school: Critical review of the literature and future directions. Review of Educational Research, 78(4), 751-796. http://dx.doi.org/10.3102/0034654308321456

Wiederkehr, V., Darnon, C., Chazal, S., \& Guimond, S. (2015). From social class to self-efficacy: internalization of low social status pupils' school performance. Social Psychology of Education, 18(4), 769-784. http://dx.doi.org/10.1007/s11218-015-9308-8.

Zeldin, A. L., \& Pajares, F. (2000). Against the odds: Self-efficacy beliefs of women in mathematical, scientific, and technological careers. American Educational Research Journal, 37(1), 215-246. http://dx.doi.org/10.3102/00028312037001215

Zimmerman, B. J., Bandura, A., \& Martinez-Pons, M. (1992). Self-motivation for academic attainment: The role of self-efficacy beliefs and personal goal setting. American Educational Research Journal, 29(3), 663-676. http://dx.doi.org/10.3102/00028312029003663 


\section{Appendix}

\section{Appendix 1. Scenario 3}

During a math class, your teacher has assigned you an online activity. He will clarify your doubts about the drafting of the problems or the instructions for completing the assignment through a virtual platform (no aspect of the activity is discussed in the classroom; it is completely online).

The activity requires you to solve a series of very difficult problems within a time limit. You may not use any device or additional help to carry out the activity.

The teacher does not provide many instructions; he does not describe how that math operations need to be performed (mentally or on paper). He did not specify if it is necessary to verify the procedures used or if there are rules to follow to present the activity.

The activity is a class exercise. You do not gain or lose points; therefore, the results will not affect your final average record. The goal is to understand much you have learned in class.

In this situation, how would you judge your ability to perform the activity?

Not capable to perform it 0--0--0--0--0--0--0--0--0--0--0 totally capable of performing it

\section{Copyright Disclaimer}

Copyright for this article is retained by the author(s), with first publication rights granted to the journal.

This is an open-access article distributed under the terms and conditions of the Creative Commons Attribution license (http://creativecommons.org/licenses/by/3.0/). 